\title{
Editorial
}

\section{On the issue of diaspora's terminological dispersal}

\author{
Ola Ogunyemi, University of Lincoln
}

\begin{abstract}
This analytical article contributes to the debate about the diaspora's terminological dispersal that has dominated scholarly discourse in the past two decades. The author argues that diaspora as a 'metaphoric designation' is a useful conceptual entry point to chart the multiplicity of ways in which diaspora research has evolved in the $21^{\text {st }}$ century. From this premise, diaspora as a 'metaphoric designation' mitigates against the 'nostalgia-premised' definitions of diasporas and could resolve the concerns about 'terminological dispersal' that have proliferated in diaspora studies.
\end{abstract}

Keywords: diaspora, metaphor, global migration, hybridity, methods, theories.

The trenchant criticism of the appropriation of the term diaspora to describe the experiences of global migrants makes one ponder, is the term relevant in the $21^{\text {st }}$ century? Notably, the term diaspora has its origins in the shared common historical experiences of dispossession, displacement, and adaptation (Clifford 2018:12) and was originally applied to the Jewish, African, Armenian and Irish diasporas.

Some of the concerns raised about the use of the term include that it was used far too loosely and that it was often used to describe any community that in one way or another has a history of migration (Cohen 1997). Critics argue that although diasporas originate as a dispersion or a migration, not all dispersals can be defined as diasporas and that it is sometimes used to describe migrants who do not have a homeland to which to return or who can no longer identify with the homeland (Stierstorfer and Wilson, 2018:xv). Therefore, critics conclude that its use is not only indiscriminate but also erodes its distinctiveness and usefulness as a descriptive tool in research (Brubaker, 2005; Braziel \& Mannur, 2003:3).

The use of the term diaspora is complicated by the fact that there are no universal characteristics of the term in diaspora literature. For Safran (1991), they include dispersion, memory, alienation, ancestral homeland, restoration, and affective connection with homeland (ibid:83-84). For Cohen (2008), they include dispersal, pursuits of work/trade, collective memory/myth, imagined ancestral home, vicarious relationship, intermittent visits, group consciousness, transmission of cultural/religious heritage, lack of acceptance/discrimination in host societies, empathy/co-responsibility and tolerance for pluralism (see Cohen 2018:19). And for Vertovec (1999), they encompass a social form, a type of consciousness and a mode of cultural production.

However, other scholars countered that the focus should shift to the conditions of diaspora. From this perspective, Braziel and Mannur (2003) note that the term has moved from essentialists notions of homeland, national or ethnic identity, and geographical location to.....terms of hybridity, metissage, or heterogeneity (ibid:5-6). And Butler (2001) argues for a framework of diaspora that contends with the reasons for dispersal, relationship to both the 
homeland and the hostland, relationships within the diasporic community, and comparative diaspora studies (ibid:195).

However, there has never been a better time to do diaspora research than now. The global flow of total migration and, forced expatriates topped 272 million in 2019, an increase of 51 million since 2010 (UN DESA 2019). This rise calls for a better understanding of movements of people and the wider political and socio-economic ramifications for the host and home countries. Statistics across continents shows that Europe hosted the largest number of international migrants ( 82 million), followed by Northern America (59 million), Northern Africa and Western Asia (49 million) (UN DESA 2019).

At the country level, about half of all international migrants reside in just 10 countries, with the United States of America hosting the largest number of international migrants (51 million), equal to about 19 per cent of the world's total. Germany and Saudi Arabia host the second and third largest numbers of migrants (13 million each), followed by the Russian Federation (12 million), the United Kingdom (10 million), the United Arab Emirates (9 million), France, Canada and Australia (around 8 million each) and Italy (6 million) (UN DESA 2019). Notably, the arrival of over 1 million people in Europe in 2015 to escape the war in Libya, Syria, Iraq and Afghanistan not only caused a major political and social upheaval in Europe, but also turned the initial welcome into anti-migrant sentiments (BBC 2015).

Despite the concerns about deviation from diaspora's historical origins, three broad enduring characteristics are retained which makes the term relevant in the $21^{\text {st }}$ century, that is, dispersion, affective connection and identity maintenance. In exploring these, scholars should focus on the political and socio-cultural functions these characteristics serve the migrant groups. These functions, in this context, refer to diaspora consciousness to the group itself and its social functions to others (Shuval, 2000:47). In arguing for this approach, Cohen (2019) notes that the central issue is not so much whether the concept of diaspora has been appropriately used or improperly abused, but what function it is serving to the many ethnic groups that have adopted it (ibid:28). And Shuval (2000) added that a diaspora culture helps maintain a sense of community and belonging to a more rewarding and welcoming social entity (ibid:47).

The term diaspora is also relevant because of its adaptability as a theoretical framework. For instance, it is widely linked to a range of theories including ethnic theory (i.e. the processes 
involved in deriving shared identities from commonalities of history, language/religions and past achievements (Shuval, 2000:44); globalization/transnationalism (i.e. a sense of being part of an ongoing transnational network that includes a homeland (ibid); and to other theories such as identity; political theory; citizenship; journalism; and peace. It is also relevant because it enables methodological rigour. For instance, diaspora's study design encompasses a range of methods including qualitative, quantitative and mixed methods.

The major challenge is how to identify the functions the term serves to diaspora groups in previous studies and how to capture it in future study design. In this Editorial, I will focus on the former through a scoping review of the 39 chapters in an edited book by Jessica Retis and RozaTsagarousianou (2019). This edited book was chosen not only because it is the most recent volume on diaspora research in relation to media, culture and communication, but also because it covers more diverse elements of diaspora formation and mediation unlike other books which are narrowly focussed on some of these specific elements. For example, Digital Diaspora by Gajjala (2019) focused on a selectin of contemporary (gendered) Indian identified networks online; Diaspora and Media in Europe by Karim Karim \& Al-Rawi (2018) has a narrow geographical scope by focusing on diasporas' use of media to communicate among themselves and to integrate into European countries; The Routledge Diaspora Studies Reader by Stierstorfer and Wilson (2018) focused on the emergence and development of diaspora studies as a field of scholarship; Media, Diaspora and Conflict (2017) by Ola Ogunyemi focused on the roles of diasporic media in escalating and deescalating conflicts; and Diasporas in the New Media Age by Alonso \& Oiarzabal (2010) focussed on the social use of technologies by emigrants and diasporas.

In my scoping review, I have adopted metaphor as an analytical tool to reveal these functions. Furthermore, I made note of other relevant characteristics of study such as the participants of study, modes of communication, links to other theories, study design, and study settings. To clarify, the participants of the study refer to the diaspora group itself, the host country and the homeland which may be real or virtual (Sheffer, 1986). The modes of communication refer to written and oral media, electronic media including the internet and the World Wide Web, as well as relatively cheap means of transportation to all corners of the globe (Shuval, 2000:44).

\section{Functions the term diaspora serves to diaspora groups}

By understanding a metaphor, we know better its usefulness as a crucial source of influence (Lakoff, 1991) and its pervasiveness in everyday life, not just in language but in thought and action (Lakoff and Johnson (2003). Scholars have explored metaphors in a range of topics including time (Clark, 1973; Moore, 2006); emotions (Kovecses, 2003); personal relationships (Winter and Matlock, 2013); economics (Henderson, 1982); politics (Lakoff, 2008); crime (Thibodeau and Boroditsky, 2011); the internet (Matlock et al, 2014); and immigration (Santa Ana, 2002) among others.

Safran (1991) was on point in noting that diaspora is used as a 'metaphoric designation' for several categories of people including expatriates, expellees, political refugees, alien residents, immigrants, and ethnic and racial minorities tout court (ibid:83). However, there is little scholarly acknowledgement of how metaphors are used to communicate the functions diaspora serve to diaspora groups.

The scoping review confirms that the focus of diaspora research has shifted from the historical characteristics of dispersal, myths and memories to other characteristics such as migration, identity, integrations, engagement, and transnational linkages. The review also confirms that the term diaspora is applied to diverse groups including ethnic, expatriates, 
minority, transnational migrants, political refugees, asylum seekers, illegal immigrants, dispersed economic migrants, nomads, sojourners, tourists and exiles (Stierstorfer and Wilson, 2018:xiv).

The review identified some notable metaphors including loss, identity, relationship, engagement, development, intersectionality, nationalist, cultural production and mediation. For instance, the loss metaphor connotes the construction of collective experiences of loss, such as family, home, or hope of returning to a place one was born in (Cho, 2007:180; Witteborn, 2019). Hence, Witteborn (2019) argues that diasporic subjectivities do not just emerge out of dislocation from a territory but from the knowledge of loss (ibid). The group this metaphor serves the most are migrants regarded as asylum seekers, refugees, and new arrivals. For them, the metaphor serves the function of a resource in the struggle against dispossession and for the creation of support networks (ibid:188). The term diaspora in this context is linked to transnationalism and the geographical foci of the chapters in this review are the Europe and the Asia. The method commonly used in this type of study is grounded approach. The result of studies indicates that digital technology is one of the drivers of the transformation of experiences of loss into experiences of participation, self-presentation, and social alliances (ibid).

The identity metaphor denotes the diasporas' perception of themselves as diaspora and construction of the appropriate discourses and engagement in collective action (Tsagarousianou, 2019). To illustrate, Sprio's (2019) study found that Anglo-Italians felt a sense of in-betweenness, of never fully belonging in one world or another, not being British enough or Italian enough (ibid). For these diaspora groups, this metaphor serves the function of shaping discourse on identity politics and their reactions to them. The scoping review reveals that the term diaspora is linked to other theories such as hybrid/multilayered identities, identity politics, multiculturalism, globalisation discourse of integration, interculturality, public sphere, discourse analysis, concepts of event, race relations, framing and transnationalism. The geographical foci of the chapters in this review are the Europe, the Australia, the Asia, the North America and the South America. And the methods include interviews using a combination of nonprobability sampling techniques, snowball sampling, critical discourse analysis, framing analysis, online distribution methods, survey data drawn from a random sample, Delphi method, and grounded approach. Most importantly, the result of study postulates that cultural trauma occurs when diaspora groups associate their identities with the traumatic experiences of groups in other places or in the homeland (Tsagarousianou, 2019).

The relationship metaphor denotes diasporas' actions to forge and sustain multi-stranded social relations that link together their societies of origin and settlement (Basch, Glick Schiller, \& Szanton Blanc, 1992:7; Moreno-Esparza, 2019:415). To illustrate, Wall et al's (2019) study demonstrates that immigrants need information about the situation back home such as whether it was safe to return, how family and friends were faring, as well as the condition of people's homes left behind (ibid: 509). For the diasporas, this metaphor functions as a medium of connectivity involving email, long distance calls, texts on mobile phones, videoconferencing, hometown websites (ibid). The scoping review reveals that the term diaspora is linked to other theories such as transnationalism, information precarity, public sphere, cosmopolitanism. The geographical foci of the chapters in this review are the Australia, the USA, the Middle East. The methods commonly used include field work, interviews, focus groups, comparative analysis, case study, participatory observant study, multi-sited ethnography, mobile methods and semi-structured questionnaire. Significantly, the results of research note the roles of ICTs in maintaining affective bonds and of 
adaptation/acculturation processes pertaining to the host society (ibid) and also about living relatively comfortably among different structures and cultures and managing to coexist and even collaborate with others of different backgrounds of trajectories (Nedelcu, 2012; Georgiou, 2019: 73).

The engagement metaphor denotes the multiple layers of interactions mediated by new media. For example, studies found positive deployment of new media by refugees using smartphones as 'Tripadvisor' and 'feedback networks' in navigating the migratory routes (Candidatu et al, 2019). For these diaspora groups, this metaphor functions as a medium of influence about diasporas' e-networking, participation in a public sphere (Monnier, 2019:354) and about diasporas'diverging everyday practices that are all reflective of intersecting power relations (Candidatu et al, 2019). The scoping review reveals that the term diaspora is linked to other theories including feminism, post-colonialism, nationalism. The geographical foci of the chapters in this review are the Europe and the Asia. The methods commonly used include textual analysis, interviews, questionnaires, participant observation, critical analysis, ethnographic method, comparative, multisited, and dynamic approach. Significantly, the result of study reveals some startling developments, for example, that SNSs among relatively privileged Mexican migrants in Europe often involves discriminatory practices which may encourage and reinforce exclusion and segregation (Bailey and Nessi, 2019: 526).

The development metaphor denotes a sense of collective action by self-organized communities of expatriate scientists and engineers to develop their home country or region, mainly in science, technology, and education (Nedelcu, 2019). For example, Nedelcu's (2019) study found that ICTs generate new transnational public spheres in which migrant and non-migrant populations can mobilize on common public issues in new spaces of collective action (ibid, 2019, p.492). For the diasporas, this metaphor serves the functions of enabling diaspora peoples to look back at 'home' while adopting a distant and less involved gaze (Gonnelli, 2019). The scoping review reveals that the term is linked to theories such as DevComm, and migration regulation policies. The geographical focus of the chapters in this review is the Europe and the methods commonly used include interviews, thematic content analysis. Significantly, the result of study reveals that development is a recurring discourse among diasporas about bringing change in four main sectors: education, women's empowerment, business, and health (ibid).

The intersectionality metaphor denotes the inclusion of LGBTQ individuals in diaspora research and of adoption of an intersectional approach (Dhoest, 2019: 389). For the diasporas, this metaphor serves the function of giving a sense of belonging to the minorities within diaspora groups such as Lesbian, Gay, Bisexual, Transgender and Queer (LGBTQ) individuals. The scoping review reveals that the term is linked to theories such as the intersectionality framework. The geographical focus of the chapters in this review is the Europe and the methods commonly used include case study and interview. Most significantly, the result of study reveals the benefits of reviving existing weak ties in one's social network, creating new ties, and finding access to non-institutional information (ibid).

The nationalist metaphor denotes the symbolic cultural practices among diasporas to maintain ties with home. The examples of cultural practices include teledrama club, cultural festivals, fundraising events, performing skits, dancing, and planned trips. For these diaspora groups, this metaphor serves the function of demonstrating how the consumption of media from their home countries is a salient feature among most diasporic groups (Gamag, 2019: 401). The scoping review reveals that the term is linked to theories such as nationalist discourse. The 
geographical foci of the chapters in this review are the Europe and the Australia. The methods commonly used include participant observations and in-depth interviews. Significantly, the result of study reveals how migrants draw on nationalist subjectivities of the home country when fashioning their everyday selves (ibid).

The cultural production metaphor denotes the interaction and communication across (cultural, lingual, and genetic) boundaries (Horz, 2019). For the diasporas, this metaphor serves the function of depicting how the visibility of difference in diasporic media draws diaspora groups into the center of political debates about inclusion, segregation, safety, and democracy in Europe (ibid). The scoping review reveals that the term is linked to theories such as minority access to media, participation in media institutions and the public sphere. The geographical focus of the chapters in this review is the Europe and the methods commonly used include content analysis and qualitative interviews. Most importantly, the result of study reveals how diasporic media connects the local, national, and global and can, therefore, be seen as a constituent factor of the transnational public sphere paradigm (ibid:448).

The mediation metaphor generally denotes the processes by which a given social dispensation produces and reproduces itself in and through a particular set of media (Mazzarella 2004). The social functions this metaphor serves are evident in the ways in which distinct media, genres, platforms, outlets differently allow for a specific articulation of issues or bringing together of diasporas via Facebook groups, pages, hashtag publics, discussion forums, mailing lists, WeChat or WhatsApp groups. The scoping review reveals how media technologies mediate a broad sense of belonging and connectivity through the expression of gratitude and interaction with members of the hostland; circulation of information to loved ones; navigation of migration routes and creation of a shared social spaces (Candidatu et al, 2019; Gamag, 2019). This metaphor is linked to theories such as networked individualism, intersectionality, feminist and postcolonial theories. The geographical foci of the chapters in this review are the Europe and the USA. The methods commonly used include fieldwork, critical analysis, participant observations and in-depth interviews. Most importantly, the mediation metaphor provides an insight into how distinctive medium-specific characteristics give shape to specific diaspora formations.

\section{Conclusion}

I have argued that diaspora as a 'metaphoric designation' is a useful conceptual entry point to chart the multiplicity of ways in which diaspora research has evolved in the $21^{\text {st }}$ century. However, the metaphors identified in the scoping review are not exhaustive but indicative of the diverse political, economic and socio-cultural functions diaspora serve the diaspora groups in their efforts to come to terms with the conditions of diaspora.

Notably, there are other examples of 'metaphoric designations' that help diasporas to construct a sense of being which fall outside the central focus of the literature in this scoping review. For example, the political influence metaphor connotes a sense of diasporas' contribution to the public sphere. For example, the British Sikh Association publish an annual report to assess the views of Sikhs living in the UK and to provide this information to the government, non-governmental organisations, companies and other groups. It is one of the largest projects to study the needs and wants of Sikhs in the UK (British Sikh Report, 2012). The economic metaphor connotes a sense of contribution to socio-economic development in the homeland. For example, the World Bank (2019) notes that remittance flows to low and middle income countries are expected to reach $\$ 551$ billion in 2019 , up by 4.7 percent compared to 2018 . 
The human capital metaphor connotes the construction of a sense of collective action and relevance. For example, countries like India have established ministries to address the needs of diaspora populations. Ministry for Overseas Indian Affairs was formed in 2004 to address the lack of government policy coordination on migration and to implement programmes that reach out to the Indian diaspora. Bangladesh and Sri Lanka also have established ministries to engage their diasporas (Guardian 2013). While Nigeria enacts a national policy on diaspora which states that Nigeria has recognized the Diaspora as a veritable tool for the socioeconomic development of the country leading to the desire to draw a national policy that guarantees their right of participation in the socio-economic development of their home land (Nigerians in Diaspora Commission)

The solidarity metaphor connotes a sense of global community and recognition. For example, the African Union (AU) set up a Diaspora Division to respond to the needs of communities throughout the world that are descended from the historic movement of peoples from Africa; predominantly from the Americas, Europe and the Middle East, among other areas around the globe (AU). And the Global Knowledge Partnership on Migration and Development (KNOMAD) successfully advocated to have goals related to migration included among the Sustainable Development Goals (KNOMAD).

From this premise, diaspora as a 'metaphoric designation' mitigates against the 'nostalgia-premised' definitions of diasporas (Tsagarousianou, 2019: 83) and could resolve the concerns about 'terminological dispersal' (Smets, 2019) that have proliferated in diaspora studies in the past two decades.

\section{The articles in this maiden edition}

The launch of the journal of Global Diaspora and Media is both timely and necessary to further advance scholarship to promote a global turn in diaspora research in relation to media, culture, communication from interdisciplinary perspectives and to facilitate engagement and interaction with communities, agencies and governments both at home and host nations. Moreover, the journal will be a forum for diaspora journalists to share ideas and experiences about aspects of journalism practice with scholars and the wider community.

The response to the Calls for Papers in 2019 was very high from the members of the Diaspora, Migration and the Media, a thematic section of the European Communication Research and Education Association (ECREADMM) and the members of the Diaspora and Media working group of the International Association for Media and Communication Research (IAMCR/DiM). This is an indication of not only the quantity but also the quality of research on diasporic media and audiences. The diversity and quality of manuscripts received made the selection of articles for publication in this maiden edition a difficult editorial task. These articles evidenced multiple 'metaphoric designations' that underpin some of the diverse political, economic and socio-cultural functions the term diaspora serves to diaspora groups while contributing to our existing knowledge of global diaspora and their media in their quest to come to terms with the conditions of diaspora.

\section{Acknowledgement}

The editor would like to thank the editorial and advisory board members for their intellectual contribution to this journal project during the peer review process. 


\section{References}

African Union. The Diaspora Division. https://au.int/en/diaspora-division accessed on 21 Oct., 2019.

Alonso, A. and Oiarzabal, P. J. (eds.) (2010) Diaspora in the New Media Age. Reno: University of Nevada Press.

Bailey, O. and Nessi, L. (2019) Racial and Class Distinctions Online The Case of the Mexican European Diaspora on Social Networking Sites. In Jessica Retis and RozaTsagarousianou. The Handbook of Diaspora, Media and Culture, pp.515 - 528. New Jersey:Wiley-Blackwell.

Basch, L., Glick Schiller, N., \& Szanton Blanc, C. (1992). Nations unbound: Transnational projects, postcolonial predicaments, and deterritorialized nation-states. London, UK/New York, NY: Routledge.

BBC (2015) Migrant crisis: One million enter Europe in 2015 https://www.bbc.co.uk/news/world-europe-35158769 accessed on 21 Oct., 2019.

Braziel, J. E. and Mannur, A. (2003) Nation, Migration, Globalization: Points of Contention in Diaspora Studies. In Jana Evans Braziel and Anita Mannur (Eds) Theorizing Diaspora, pp. 1 - 22. Oxford: Blackwell.

Braziel, J. E. and Mannur, A. (Eds) (2003) Theorizing diaspora. Maiden, MA:Blackwell.

British Sikh Report https://en.wikipedia.org/wiki/British_Sikh_Report accessed on 21 Oct., 2019.

Brubaker, R. (2005) 'The “Diaspora” Diaspora'. Ethnic and Racial Studies 28.1:1-19.

Butler, K. D. (2001). Defining diaspora, refining a discourse. Diaspora: A Journal ofTransnational Studies, 10(2), 189-219.

Candidatu, L., Leurs, K. and Ponzanesi, S. (2019) Digital Diasporas: Beyond the Buzzword Toward a Relational Understanding of Mobility and Connectivity. In Jessica Retis and Roza Tsagarousianou. The Handbook of Diaspora, Media and Culture, pp.31-48.New Jersey:Wiley-Blackwell.

Clark, H. H. (1973) Space, time, semantics, and the child. In Moore, T. (ed.) Cognitive Development and the Acquisition of Language. New York: Academic Press, pp. 27 - 63.

Clifford, J. (2018) Diasporas. In Klaus Stierstorfer and Janet Wilson (Eds) The Routledge Diaspora Studies Reader, pp. 10 - 16. London: Routledge.

Cho, L. (2007). The turn to diaspora. Topia: Canadian Journal of Cultural Studies, 17, $11-$ 30. http://topia.journals.yorku.ca/index.php/topia/article/view/13229 accessed on 22 Nov., 2019. 
Cohen, R. (1997) Global Diasporas: An Introduction. UCL Press. London.

Cohen, R. (2008) Global Diaspora: An Introduction. $2^{\text {nd }}$ Edition. London and New York: Routledge.

Cohen, R. (2019) Diasporas Changing Meanings and Limits of the Concept. In Jessica Retis and Roza Tsagarousianou. The Handbook of Diaspora, Media and Culture, pp.23-30.New Jersey:Wiley-Blackwell.

Dhoest, A. (2019) Intersections and (Dis)Connections LGBTQ Uses of Digital Media in the Diaspora. In Jessica Retis and Roza Tsagarousianou. The Handbook of Diaspora, Media and Culture, pp.387 - 400. New Jersey:Wiley-Blackwell.

Gajjala, R. (2019) Digital Diasporas. Labor and Affect in Gendered Indian Digital Publics https://www.rowmaninternational.com/book/digital_diasporas/3-156-41991552-356f-4b5ca2da-a138363d44c7 accessed on 13 Feb., 2020.

Gamag, S. R. (2019) Sri Lankan Migrant Women Watching Teledramas in Melbourne A Social Act of Identity. In Jessica Retis and Roza Tsagarousianou. The Handbook of Diaspora, Media and Culture, pp.401 - 414.New Jersey:Wiley-Blackwell.

Georgiou, M. (2019) Diaspora and the Plurality of Its Cosmopolitan Imaginaries. In Jessica Retis and Roza Tsagarousianou. The Handbook of Diaspora, Media and Culture, pp.6376.New Jersey:Wiley-Blackwell.

Global Knowledge Partnership on Migration and Development (KNOMAD) https://www.knomad.org/ accessed on 21 Oct., 2019.

Gonnelli,M. (2019) Somali Development Agents as Development Communicators Visions and "Religious" Challenges. In Jessica Retis and Roza Tsagarousianou. The Handbook of Diaspora, Media and Culture, pp.358 - 372. New Jersey:Wiley-Blackwell.

Guardian (2013) How to improve diaspora engagement https://www.theguardian.com/global-development-professionalsnetwork/2013/feb/20/improving-asian-diaspora-insitutions Wednesday 20 February. Accessed 21 October 2019.

Henderson, W. (1982) Metaphor in economics. Economics 18(4):147 - 153.

Henson, B. (2019) Low Frequencies in the Diaspora The Black Subaltern Intellectual and Hip-Hop Cultures. In Jessica Retis and Roza Tsagarousianou. The Handbook of Diaspora, Media and Culture, pp. 461 - 473. New Jersey:Wiley-Blackwell.

Horz, C. (2019) Between Access and Exclusion Iranian Diasporic Broadcasting in Open TV Channels in Germany. In Jessica Retis and Roza Tsagarousianou. The Handbook of Diaspora, Media and Culture, pp. 445 - 459. New Jersey:Wiley-Blackwell.

Karim H. Karim, Al-Rawi, Ahmed (2018) (Eds) Diaspora and Media in Europe: Migration, Identity and Integration. Basingstoke: Palgrave Macmillan. 
Kovecses, Z. (2005) Metaphor and Emotion: Language, Culture and Body in Human Feeling. Cambridge: Cambridge University Press.

Lakoff, G. (1991) Metaphor and war: The metaphor system used to justify war in the Gulf. www.2.iath.virginia.edu/sixties/HTML_DOCS/Texts/Scholarly/Lakoff_Gulf_Metaphor_1.ht $\underline{\mathrm{ml}}$ accessed 01 November 2019.

Lakoff, G. And Johnson, M. (2003) Metaphors WE Live by. Chicago, IL: University of Chicago Press.

Lakoff, G. (2008) The Political Mind: Why You Can't Understand $21^{\text {st }}$ Century Politics with an $18^{\text {th }}$ Century Brain. New York: Penguin Books.

Matlock, T. Castro, S. C., Fleming, M. et al. (2014) Spatial metaphors of web use. Spatial Cognition and Computation, 14(4):306-320.

Mazzarella, W. (2004). Culture, globalization, mediation. Annual Review of Anthropology,

$33,345-67$.

Monnier, A.(2019) Online Diasporas Beyond Long-Distance Nationalisms. In Jessica Retis and Roza Tsagarousianou. The Handbook of Diaspora, Media and Culture, pp.343 - 357. New Jersey:Wiley-Blackwell.

Moore, K. E. (2006) Space-to-time mappings and temporal concepts. Cognitive Linguistics 17: $199-244$.

Moreno-Esparza, G. (2019)Digital Diasporas Accounting for the Role of Family Talk in Transnational Social Spaces. In Jessica Retis and Roza Tsagarousianou. The Handbook of Diaspora, Media and Culture, pp.415 - 428. New Jersey:Wiley-Blackwell.

Nedelcu, M. (2012). Migrants' new transnational habitus: Rethinking migration through a cosmopolitan lens in the digital age. Journal of Ethnic and Migration Studies, 38, 1339-1356.

Nedelcu, M. (2019) The Romanian Scientific E-Diaspora Online Mobilization, Transnational Agency, and Globalization of Domestic Policies. In Jessica Retis and Roza Tsagarousianou. The Handbook of Diaspora, Media and Culture, pp. 491 - 502. New Jersey:Wiley-Blackwell.

Nigerians in Diaspora Commission. National Policy on Diaspora.

https://nidcom.gov.ng/national-policy-on-diaspora/ accessed on 21 Oct., 2019.

Ogunyemi, O. (2017) (Ed.) Media, Diaspora and Conflict. Basingstoke: Palgrave Macmillan.

Retis, J. and Tsagarousianou, R. (2019)The Handbook of Diaspora, Media and Culture.New Jersey: Wiley-Blackwell.

Safran, W. (1991) Diaspora in Modern Societies: Myths of Homeland and Return. Diaspora $1(1), 83-99$.

Santa Ana, O. (2002) Brown Tide Rising: Metaphors of Latinos in Contemporary American Public Discourse. Austin, TX: University of Texas Press. 
Sheffer, G. (1986) (Ed.) Modern Diasporas in International Politics. Croom Helm. Sydney.

Shuval, J. T. (2000) Diaspora Migration: Definitional Ambiguities and a Theoretical Paradigm. International Migration, Vol. 38(5):41 - 57.

Smets, K. (2019) Doing Diasporic Media Research: Methodological Challenges and Innovations. In Jessica Retis and Roza Tsagarousianou. The Handbook of Diaspora, Media and Culture, pp. 97 - 112. New Jersey:Wiley-Blackwell.

Sprio, M. (2019) Italian Post-War Migration to Britain Cinema and the Second Generation. In Jessica Retis and Roza Tsagarousianou. The Handbook of Diaspora, Media and Culture, pp.429 - 441. New Jersey:Wiley-Blackwell.

Stierstorfer, K. and Wilson, J. (2018) General Introduction. In Klaus Stierstorfer and Janet Wilson (Eds) The Routledge Diaspora Studies Reader, pp. xiii - xxv. London: Routledge.

Thibodeau, P. H. and Boroditsky, L. (2011) Metaphors we think with: The role of metaphor in reasoning. PLoS One 6(2):e16782.

Tsagarousianou, R. (2019) Beyond the Concept of Diaspora? Reevaluating our Theoretical Toolkit Through the Study of Muslim Transnationalism. In Jessica Retis and Roza Tsagarousianou. The Handbook of Diaspora, Media and Culture, pp.77-96. New Jersey:Wiley-Blackwell.

United Nations Department of Economic and Social Affairs (UN DESA, 2019) Population Facts

https://www.un.org/en/development/desa/population/migration/publications/populationfacts/d ocs/MigrationStock2019 PopFacts_2019-04.pdf accessed on 29 Jan., 2020.

Vertovec, S. (1999) three meanings of "diaspora", exemplified among South Asian religions. Diaspora: A journal of Transnational Studies, 6(3), 277 - 299.

Wall, M. Campbell, M. O. \& Janbek, D. (2019)Refugees, Information Precarity, and Social Inclusion The Precarious Communication Practices of Syrians Fleeing War. In Jessica Retis and Roza Tsagarousianou. The Handbook of Diaspora, Media and Culture, pp503 - 514.New Jersey:Wiley-Blackwell.

Winter, B. and Matlock, T. (2013) Reasoning about similarity and proximity. Metaphor \& Symbol 28:1-14.

Witteborn, S.(2019)Digital Diaspora Social Alliances Beyond the Ethnonational Bond. In Jessica Retis and Roza Tsagarousianou. The Handbook of Diaspora, Media and Culture, pp.179-192.New Jersey:Wiley-Blackwell.

World Bank (2019) Data release: Remittances to low- and middle-income countries on track to reach $\$ 551$ billion in 2019 and $\$ 597$ billion by 2021 .

https://blogs.worldbank.org/peoplemove/data-release-remittances-low-and-middle-incomecountries-track-reach-551-billion-2019 accessed on 21 Oct., 2019. 
